Review

\title{
Background Conditions and Mining Pollution throughout History in the Río Tinto (SW Spain)
}

\section{Manuel Olías ${ }^{1, *}$ and José Miguel Nieto ${ }^{2}$}

1 Department of Geodynamics and Palaeontology, University of Huelva, Campus "El Carmen", 21071 Huelva, Spain

2 Department of Geology, University of Huelva, Campus "El Carmen”, 21071 Huelva, Spain; E-Mail: jmnieto@uhu.es

* Author to whom correspondence should be addressed; E-Mail: manuel.olias@dgyp.uhu.es; Tel.: +34-959-219-864; Fax: +34-959-219-440.

Academic Editor: Yu-Pin Lin

Received: 19 April 2015 / Accepted: 17 June 2015 / Published: 26 June 2015

\begin{abstract}
The Río Tinto drains the eastern part of the Iberian Pyrite Belt (IPB), an area with a huge amount of massive sulphide deposits that has been mined for the last 4500 years. This river presents extreme conditions, with very high concentrations in solution of metals and metalloids and low $\mathrm{pH}$ values. Mining activities in the upper part of the watershed of the Río Tinto have been documented since historical times and a huge amount of widespread acid-producing mine residues exist in this area. Nevertheless, there is no consensus among the scientific community as to whether the extreme conditions of the Río Tinto are the result of natural processes or the intense mining activity in the region. Here we show, using numerous geological, archaeological and historical records, that the present quality of the Río Tinto is the result of mining activities, especially during the period 1850-2001, while natural processes of formation of acid rock drainage can be considered negligible.
\end{abstract}

Keywords: sulphide deposits; acid mine drainage; Iberian Pyrite Belt 


\section{Introduction}

\subsection{Acid Mine Drainage}

Acid mine drainage (AMD) is one of the biggest environmental problems associated with the mining of sulphide-rich mineral deposits, being responsible for the pollution of surface and groundwater in the vicinity of mining areas [1]. AMD results from the oxidative dissolution of pyrite together with other less abundant sulphide minerals (sphalerite, galena, chalcopyrite, arsenopyrite, etc.) generally associated with metal-bearing mineral deposits. Its generation is the result of the exposure of sulphides to air, water and microorganism, and involves complex processes governed by a combination of physical, chemical, and biological factors, as has been recently discussed in a review of the current state-of-the-art of AMD [2].

Sulphide oxidation occurs naturally in the zones where these minerals are in contact with the atmosphere; this is known as acid rock drainage (ARD). However, under natural conditions, most of the sulphides remain buried under anoxic conditions and only a small fraction outcrops and is exposed to the action of oxygen and water. Mining activities enhance the generation of acidic leachates because they increase the exposure of sulphides to air, water, and microorganisms by: crushing of the sulphide-rich rocks increasing the surface area exposed, drilling tunnels and galleries that allow atmospheric oxygen to come into contact with buried sulphides, depressing the water table, etc. $[3,4]$.

In many mines, once extractive activity ceases, increased concentrations of contaminants in the water are produced due to the recovery of groundwater levels and the redissolution of many salts precipitated in the unsaturated zone. Subsequently, the concentrations decline but can still stay elevated for hundreds and even thousands of years [5].

\subsection{Study Area}

The Río Tinto basin drains mainly materials belonging to the Iberian Pyrite Belt (IPB), which in turn forms part of the South Portuguese Zone of the Hercynian Iberian Massif. Only in the southern part of the watershed the river runs through Neogene materials, mainly marly deposits (Figure 1). The IPB, a $230 \mathrm{~km}$ long by around $50 \mathrm{~km}$ wide strip extending from the Seville province to the southwest of Portugal, comprises three lithological groups from Devonian to Middle Carboniferous [6]: (1) the Phyllite-Quartzite Group (PQ), formed by a sequence of shales and sandstones with an estimated thickness of at least $>2000 \mathrm{~m}$ [7], (2) the Volcano-Sedimentary Complex (VSC), which overlies the PQ group and includes a mafic-felsic volcanic sequence interstratified with shales, and (3) the Culm Group, overlying the VSC, a turbidite sequence of shales, sandstones and conglomerates.

The IPB contains one of the greatest concentrations of polymetallic massive sulphide mineralization on Earth [6], which occurs as concordant tabular bodies or lenses, commonly underlain by crosscutting stockworks in which sulphides occur in veins and as pervasive disseminations [8]. Among them, the largest individual polymetallic sulphide deposit (original reserves of $500 \mathrm{Mt}$ sulphides) is the Río-Tinto orebody, which lies in an east-west anticline, consisting of three distinct mineralized zones: San Dionisio, San Antonio and Cerro Colorado. Cerro Colorado orebody is formed by South Lode and North Lode, being the later formed by Dehesa, Lago and Salomon orebodies. A central stockwork interconnects Filón Norte and Filón Sur. These orebodies contain pyrite $\left(\mathrm{FeS}_{2}\right)$ with minor chalcopyrite 
$\left(\mathrm{CuFeS}_{2}\right)$, arsenopyrite $(\mathrm{FeAsS})$, sphalerite $(\mathrm{ZnS})$ and galena $(\mathrm{PbS})$. They are covered by a weathering layer of gossans formed by an intense chemical weathering that can reach up to $70 \mathrm{~m}$ thick. At the north of Río-Tinto mine, there is another mining complex, Peña de Hierro, of lesser importance compared with Río-Tinto mine.

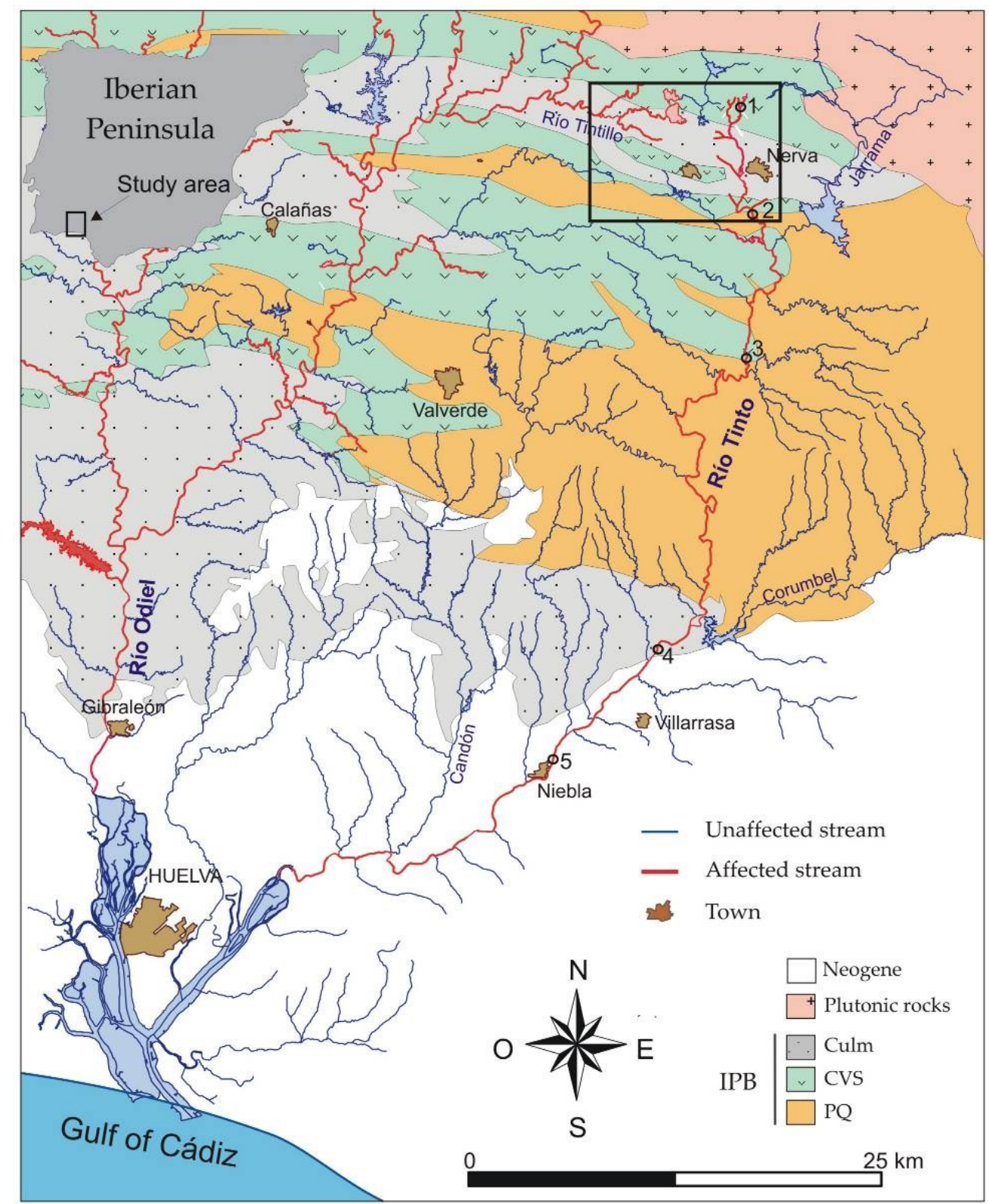

Figure 1. Map of the Río Tinto basin, in red fluvial reaches affected by acid conditions.

The main tributaries of Río Tinto are the Jarrama and the Corumbel rivers on its left bank, which have been regulated by reservoirs, and the Candón Creek on its right bank (Figure 1). As the slope decreases, the river broadens losing its fluvial character in the surroundings of Huelva and joining the Odiel River in a common estuary known as Ría of Huelva (Figure 1).

The climate in the Río Tinto basin is of a dry Mediterranean type with an average rainfall varying between $550 \mathrm{~mm}$ in the south and $900 \mathrm{~mm}$ in the upper northern hills. The rainfall is highly variable, most occurring between October and February, while it is almost non-existent during the dry season 
from June to August [9]. The Tinto basin is composed mainly by impermeable materials; therefore, the river has a low natural regulation, and most of the water discharge occurs during flood events.

\subsection{Present-Day Conditions in the Río Tinto}

The Río Tinto is a unique case worldwide of acid drainage from sulphide. Although there are many rivers affected by this problem [1,10], the supergiant sulphide deposits in the area, the absence of country rocks with acid neutralizing capacity together with the intense mining exploitation has caused extreme $\mathrm{pH}$ conditions and toxic concentrations of metals and metalloids from the headwaters to the mouth (Figure 1).

No fish, amphibians, insects or plants live in this river of acid waters. However, it is not without life; there are abundant extremophile organisms (microorganisms and certain species of algae) adapted to these particular conditions, which have attracted great scientific interest due to the existence of a wide variety of eukaryotic organisms [11-13]. Another recent interest in the Río Tinto headwaters lies in the possible similarity of these environments with conditions on Mars [14-16].

Very close to its source, the Río Tinto receives various acid leachates from the Peña de Hierro mine and subsequently receives much acid input from the Río-Tinto mine [17,18]. In this area, there is a startling landscape without vegetation and with large reddish spoil heaps, huge open pits such as Atalaya and Cerro Colorado, former industrial facilities for mineral treatment and so on [19]. These residues generate leachates with values of $\mathrm{pH}$ close to 1 and dissolved concentrations up to $84,000 \mathrm{mg} / \mathrm{L}$ of sulphate, 35,000 mg/L of Fe, $104 \mathrm{mg} / \mathrm{L}$ of As, etc.

Downstream of the mining area, contamination content decreases owing to dilution with water of uncontaminated tributaries joining the main course and attenuation processes. However, $\mathrm{pH}$ values remain at around 2.5 due to buffering by the ferric iron precipitation. Before its mouth in the estuary, the Río Tinto still has a high level of contamination, with average $\mathrm{pH}$ values close to 2.5 , dissolved concentrations of $157 \mathrm{mg} / \mathrm{L}$ of Fe, $77 \mathrm{mg} / \mathrm{L}$ of Al, etc. [20]. The Río Tinto, along with the Río Odiel, carry huge amounts of dissolved pollutants to the Huelva estuary: $7900 \mathrm{t} /$ year of Fe, $5800 \mathrm{t} /$ year of $\mathrm{Al}$, $3500 \mathrm{t} /$ year of $\mathrm{Zn}, 1700 \mathrm{t} /$ year of $\mathrm{Cu}$, etc. [21]. This, together the industrial pollution, makes the Ría de Huelva one of most polluted estuaries in Europe, with high metal concentrations in waters, sediments and biota [22 ].

The hydrogeochemical characteristics of these rivers follow a seasonal pattern. During summer, the sulphide oxidation is maximized by the increasing temperature, so that the leachate which is generated in the mining areas reaches very high concentrations. The intense evaporation causes supersaturation of various sulphate salts, which precipitate in the river banks [23]. The redissolution of these salts with the first rains of autumn causes the release of acidity, sulphates and metals, recording the highest contamination levels of the year [9].

\section{Objectives and Methods}

Numerous studies [16,24-28] attribute the current state of the Río Tinto to natural conditions related to the huge amounts of outcropping sulphides in the upper part of its watershed. This is also a widespread perception from public opinion in the zone. Other researchers explain the river conditions as being due to the existence of the sulphide deposits together with the influence of mining [1]. On the 
other hand, for the environmental restoration of mining areas it is essential to know the natural background conditions that existed before any mining activities [29].

The aim of this study is to provide information on the history of mining pollution of this river, and to discern what is natural and what is anthropogenic in its current condition. Numerous geological, archaeological and historical studies that address, partially or tangentially, some aspects of the natural features or contamination in these river systems have been collected to assess how the water quality has evolved in the Río Tinto and its environmental impact. This approach may be of interest in differentiating the importance of natural and anthropogenic processes on rivers affected by AMD.

\section{Mining History}

\subsection{The Beginning of Mining}

Metal production in the IPB began in the third millennium BC, in the Chalcolithic period, with the development of communities specializing in copper mining from carbonates, oxides and some sulphides, such as chalcocite and covellite [30]. The exploitations were restricted to minerals that outcropped at the surface or at shallow depths [27]. Between 1800 and 1200 BC, a mine seeking rich silver minerals from the oxidation of sulphides was developed. In the Late Bronze Age (1200-900 BC), mining and metallurgical activities blossomed with the Tartessian civilization, which based its economy on the production of metals [31]. With the advent of the Iron Age, new instruments allowed the miners to reach greater depths. So, there is evidence of underground works in the Río-Tinto mine in the seventh century BC [27]. Later, the Carthaginian civilization heralded the end of Tartessos and thus of mining in the IPB, until the arrival of the Romans [32].

\subsection{The Roman Period}

The arrival of the Roman Empire (second century BC) gave a strong impetus to mining, exploration, extraction, drainage systems and metallurgy. Roman technology made possible the exploitation of deposits on a hitherto unknown scale. Mining was generally underground, being silver the main metal extracted from the jarositic materials located below the gossan. Often, it was necessary to lower the water table by drainage galleries, waterwheels (Figure 2), or other systems, reaching depths of even a hundred metres. Other evidence includes caves of Roman origin (actually mines), numerous shafts and huge slag heaps.

Roman copper mining came later and exploited higher grade ores [27]. The maximum activity in this period occurred in the first century AD. After the second century, AD mines went into a gradual decline and, with the arrival of the Visigoths to the Iberian Peninsula (405 AD), the exploitation was abandoned. From the heap slags found before the beginning of modern exploitation it has been estimated the ancient extractions, mainly Roman: 800,000 t of jarositic materials for producing silver and 3,600,000 $\mathrm{t}$ of sulphides to produce $\mathrm{Cu}[33,34]$. 


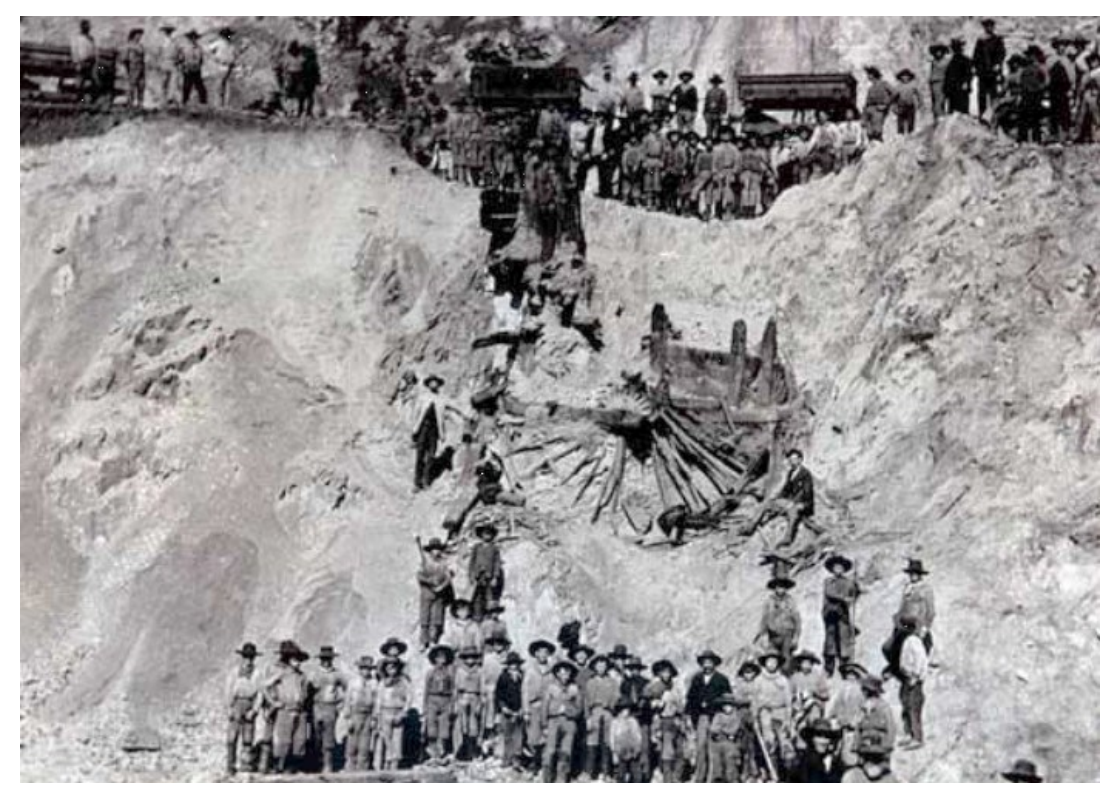

Figure 2. Roman wheel found in the early twentieth century in South Lode. It was part of a group of some 50 waterwheels, which could raise water more than $80 \mathrm{~m}$ to an adit (Río Tinto Mine Foundation).

\subsection{Since the End of the Roman Period until 1725}

It has traditionally been considered that, during the Middle Ages, mining was very scarce. However, some works attributed to the Romans could be of medieval origin because the mining technology employed by the Romans remained with little change until the late fifteenth century [27]. In the sixteenth century, there was a spate of exploring for gold and silver in the province of Huelva, which, however, did not come to fruition. It is known that, at this time, the evaporite salts that precipitate in the mining areas during the summer (Figure 3), were collected for medical purposes, dye manufacturing, etc. [35].

\subsection{The Period $1725-1849$}

The exploitation of the Río Tinto mine resumed in 1725 as a result of a grant to Robert D. Wolter; this was followed by grants to other private dealers until 1783, when the mines started to be managed by the state. Initially, copper was obtained by precipitation of the acid leachates from the Roman galleries coming into contact with scrap iron. Mining began in the South Lode extracting $\mathrm{Cu}$-rich minerals and some smelter furnaces were constructed [35]. In the late eighteenth century, mineral extractions exceeded 10,000 t/year (Figure 4). In the early nineteenth century, copper began to have multiple applications in the electrical industry, such that its global production increased by $30 \%$ per decade [24]. Mining received the final push to the mid-nineteenth century with the strong growth of the chemical industry for the manufacture of sulphuric acid, used in fertilizers, explosives, and many other products. 


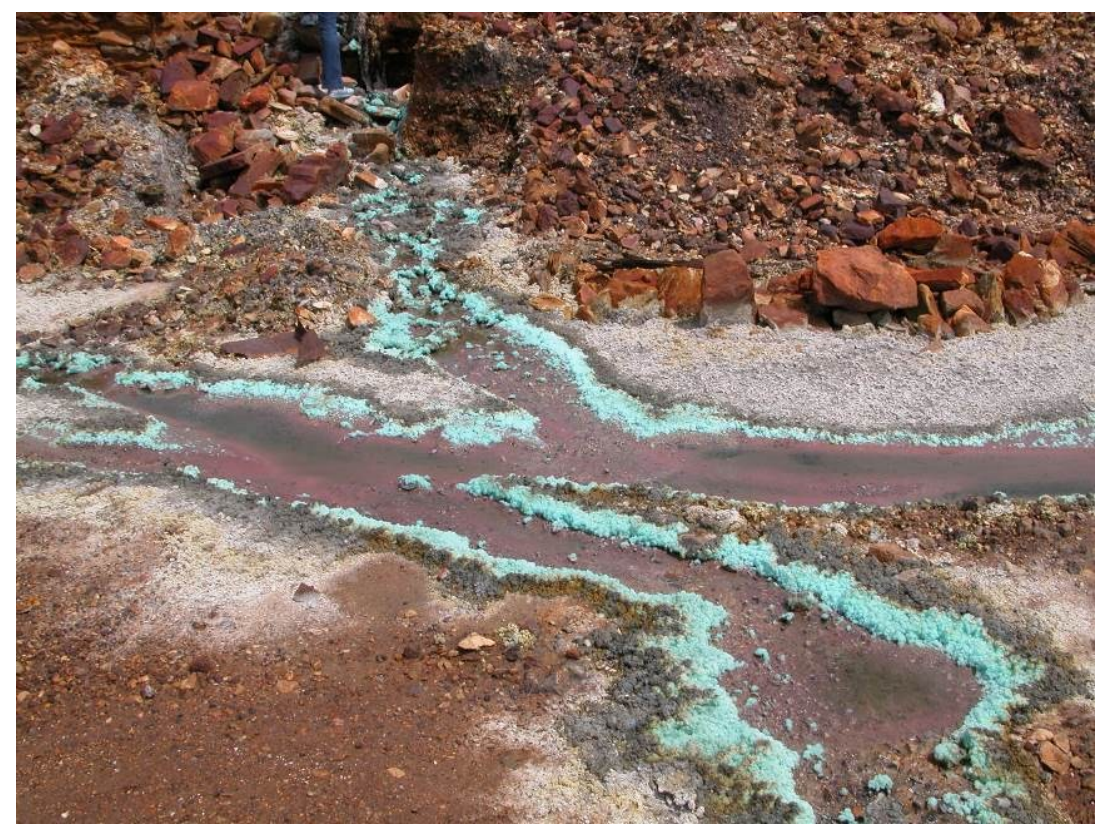

Figure 3. Evaporitic sulphate salts at the toe of a spoil heap in the Río Tinto mine. These salts were collected in the summer since the Middle Ages for the manufacture of dyes and other uses.

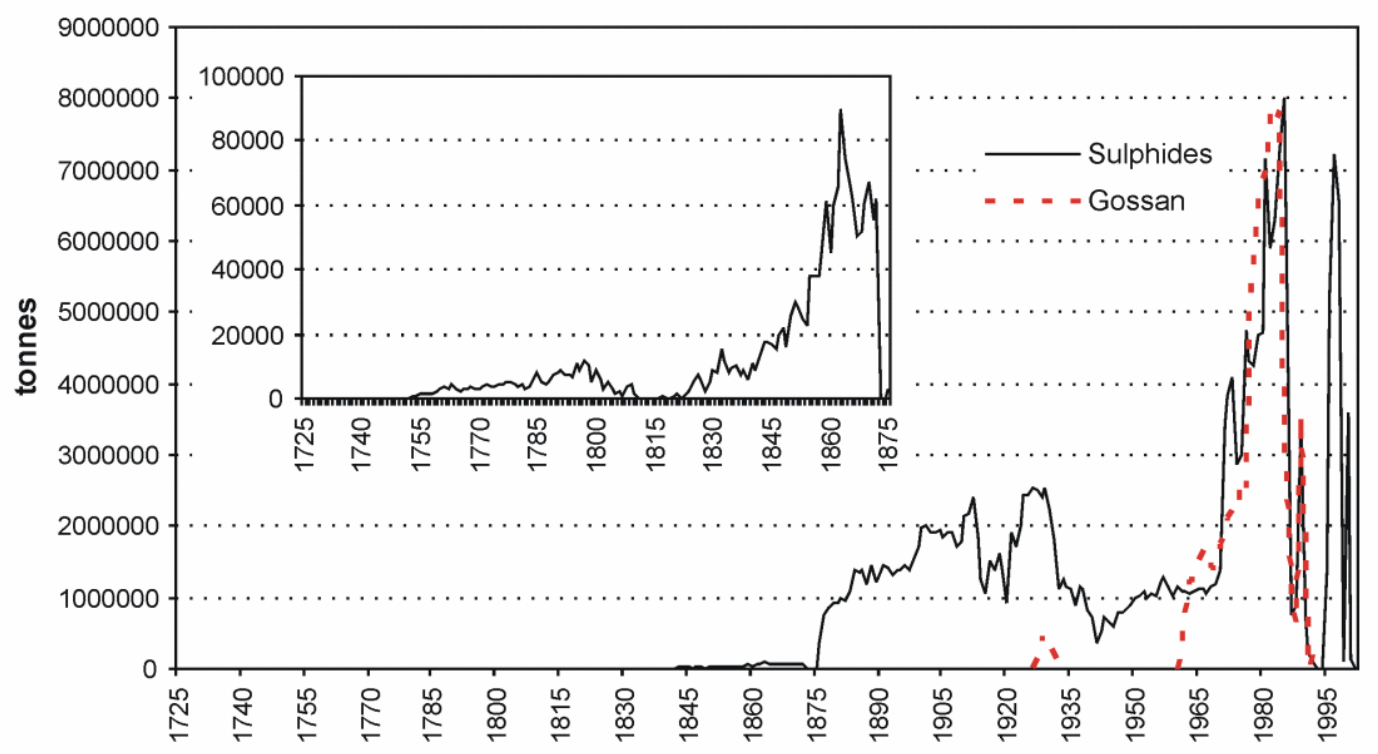

Figure 4. Evolution of sulphide and gossan production (run-of-mine ore) in the Río Tinto mine from the eighteenth century to the present.

Production at the Río-Tinto mine fell in the early nineteenth century (Figure 4) due to poor management, until completely paralysed during the Spanish War of Independence (1808-1814). To improve the performance of the mines, a concession was made to the Marquis of Remisa (1829-1849), who moved production into growth (Figure 4). New smelters, that needed significant amounts of wood and caused the disappearance of the surrounding trees, were constructed. In 1839, calcinations in "teleras" began to be used for the low grade $\mathrm{Cu}$ ores. This method involved the slow roasting (over six to seven months) of 40-50 tonnes of ore in conical heaps to remove the sulphur. Then, the roasted ore 
was placed in tanks with acidic water to dissolve the copper and cementation then produced copper in contact with iron scrap in channel systems (Figure 5). The calcination "teleras" meant less wood consumption [35]. Mineral extractions were restricted to the underground mining of a small area in the South Lode (Figure 6), distributed in six floors, reaching a maximum depth of $64 \mathrm{~m}$, less than that reached by the Romans [36]. Production in 1850 was 25,000 t of sulphides (Figure 4).

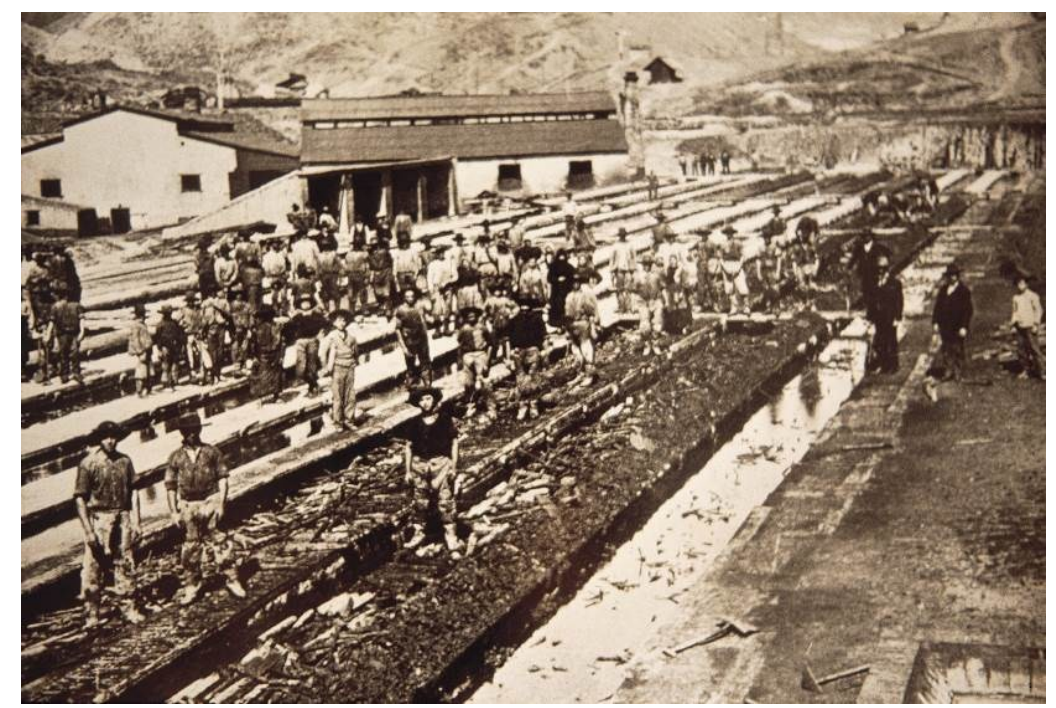

Figure 5. Channel systems for copper precipitation from acidic leachates in Zarandas-Naya zone at 1900 (Río Tinto Mine Foundation).

Until 1850, the only active mine in the IPB was Río-Tinto mine, but thereafter there was a great boom in mining sulphides and in 1855 many mines were in production, including the Peña del Hierro mine, northeast of Río-Tinto mine (Figure 7).

\subsection{The Period 1850-2001}

The state resumed exploiting the Río-Tinto mine from 1850 and production in South Lode continued to increase (Figure 4). However, by 1870, extraction ceased as a result of different problems and the government decided to sell the mines, introducing legislative changes to promote the inflow of foreign capital. In 1873, the Río-Tinto Company Limited was founded by British investors, acquiring the Río-Tinto mines.

To transport large quantities of ore the construction of a railway line to the port of Huelva was undertaken, ending in 1875 (as the rail bed Roman smelting slags were used). The mines experienced a major financial and technological push. At first, the operation was underground, but opencast mining quickly began in the South Lode (1876), three open pits in the North Lode (between 1890 and 1900) and at Atalaya (1910). In 1878, only five years after the purchase of the mines, extraction reached $900,000 \mathrm{t}, 10$ times more than the previous maximum production. For mineral processing, a new smelting plant and a factory for sulphuric acid production were constructed. 


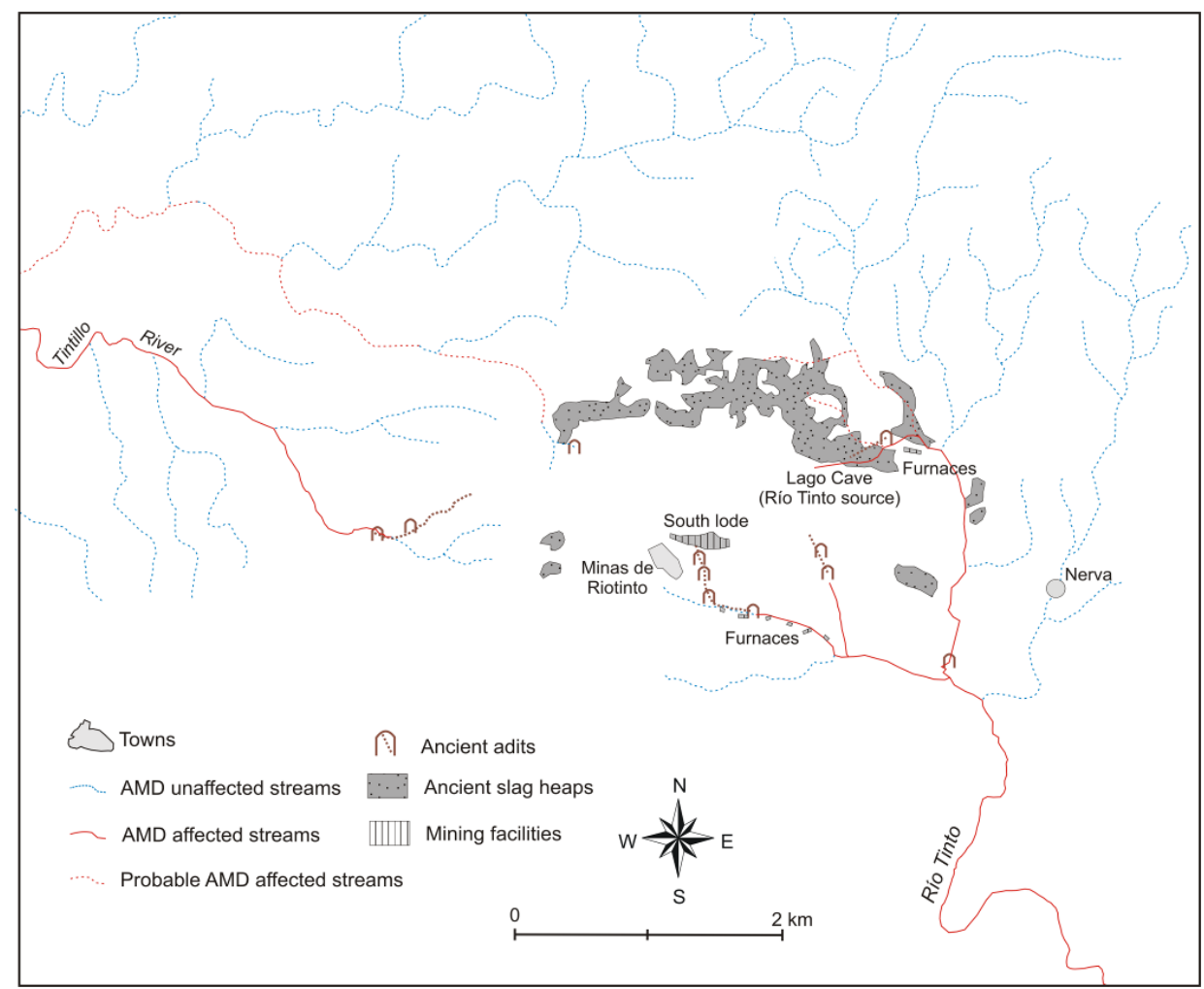

Figure 6. Reconstruction of the impact of mining in the Río Tinto headwaters before 1850 . Location of mining wastes and facilities have been taken from [36,37]. The represented area corresponds to the inner square in Figure 1.

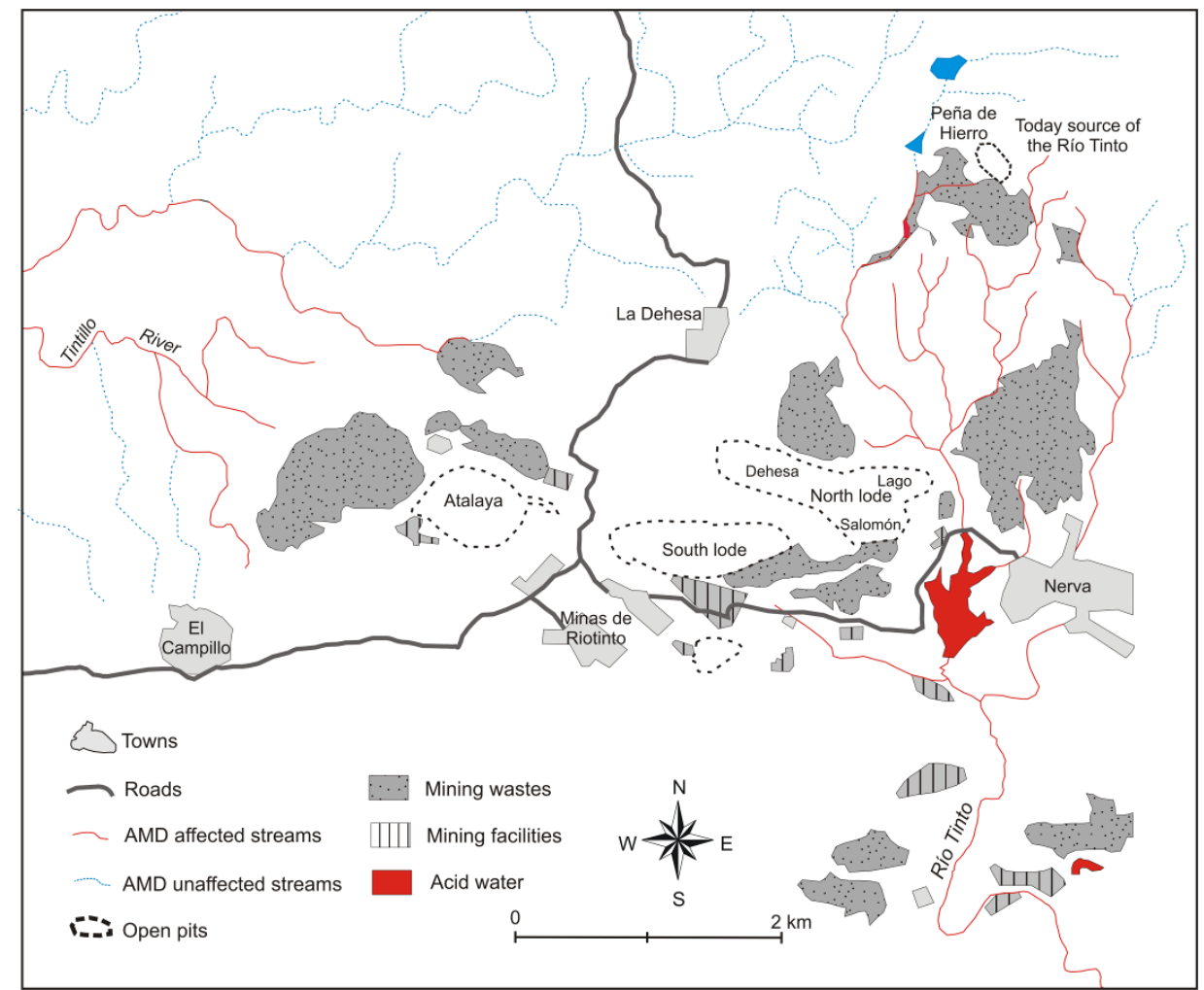

Figure 7. Reconstruction of the impact of mining in the Río Tinto headwaters in 1960. Location of mining wastes and facilities have been taken from [38]. The represented area corresponds to the inner square in Figure 1. 
Higher-grade minerals were intended for smelting or exportation. Lower-grade minerals were accumulated in large areas, directly or after calcination by "teleras", for leaching and recovery of $\mathrm{Cu}$. The calcination "teleras" aggravated environmental and public health problems (discussed below), which led to mining companies developing methods of natural cementation, which remained operational until the late 1960s [39]. For natural cementation, the ore was piled in large heaps, with holes for air inlet, and was irrigated regularly with acid mine water, so producing rapid oxidation of the sulphides. The leachates were collected and cemented in channel systems with iron scrap. The washed pyrite was used for producing sulphuric acid and thereafter roasted ashes were treated for $\mathrm{Pb}, \mathrm{Zn}, \mathrm{Co}$, Ag, etc. [39]. The underground mining works continued, especially in the South Lode and Pozo Alfredo (Figure 7). The open pits of the North Lode and the South Lode were in operation until 1930-1940, while the exploitation of Corta Atalaya continued until the end of the 20th century. The ore was taken through tunnels to the Zarandas-Naya zone (Figure 7) for treatment or rail transport to Huelva. Production underwent some fluctuations, usually ranging between 1 and 2 Mt (Figure 4), as a consequence of labour problems, variations in the market for sulphur and copper and armed conflict (the two World Wars and the Spanish Civil War).

In 1954, the Río-Tinto Company Limited sold two-thirds of its shares and management returned to Spanish investors. In 1966, a new company was formed with the aim of initiating the exploitation of Cerro Colorado and building a smelter and sulphuric acid plant in the Industrial Pole of Huelva to move production to these facilities. In the 70 s, pyrite mines declined due to competition from sulphur extracted by other industrial processes, such as desulphurization of petroleum [31]. However, global copper demand was increasing and in 1970 the opencast mine Cerro Colorado launched Cu recovery by hydrometallurgy and $\mathrm{Au}$ and Ag extraction from gossan by cyanidation. This was the stage of maximum production in Río-Tinto mine, reaching $8 \mathrm{Mt}$ of sulphides in 1985, plus gossan extraction (Figure 4). This last period of exploitation involved huge earthworks; where, 40 years ago stood the peak of Cerro Colorado, the highest in the area at $535 \mathrm{~m}$, now there is a great open pit, with a minimum altitude of $290 \mathrm{~m}$ (Figure 8). This has led to large heaps and tailing deposits in the Gossan and Copper reservoirs (Figure 8). Also, underground mining continued in Pozo Alfredo until 1987, reaching almost $600 \mathrm{~m}$ deep, and open pit mining in Atalaya until 1992.

In the $80 \mathrm{~s}$, there was a sharp drop in demand for copper and sulphuric acid [31]. Moreover, growing environmental awareness led to the ash produced in the roasting of pyritic minerals being considered a toxic residue. This provoked the closure of numerous mines in the IPB. To overcome the crisis, copper production in Río-Tinto mine was abandoned, boosting gold and silver extraction. However, a new crisis in the late 90s led to the total closure of the Río-Tinto mine in 2001. The abandonment of drainage pumping caused flooding of the underground workings and a large part of the open-pits (Figure 9).

Regarding the Peña de Hierro mine, although much less important than Río-Tinto mine, there is also evidence of its exploitation during Roman domination. Contemporary extractions started in 1853 by underground mining. In 1883, with the arrival of foreign investors, open pit mining started, with the period of maximum production occurring between 1900 and 1930 [32]. After several periods of inactivity, exploitation was completely abandoned in 1966 [40].

Today, the rising price of raw materials since 2004 due to strong demand from Asian countries has caused a rethink of the economic viability of copper mining and we are in a new cycle of resurgence. 
Thus, in the Spanish part of the IPB, two mines are currently in production: Cobre Las Cruces and Aguas Teñidas, while Río-Tinto mine and other projects are awaiting permission to reopen.

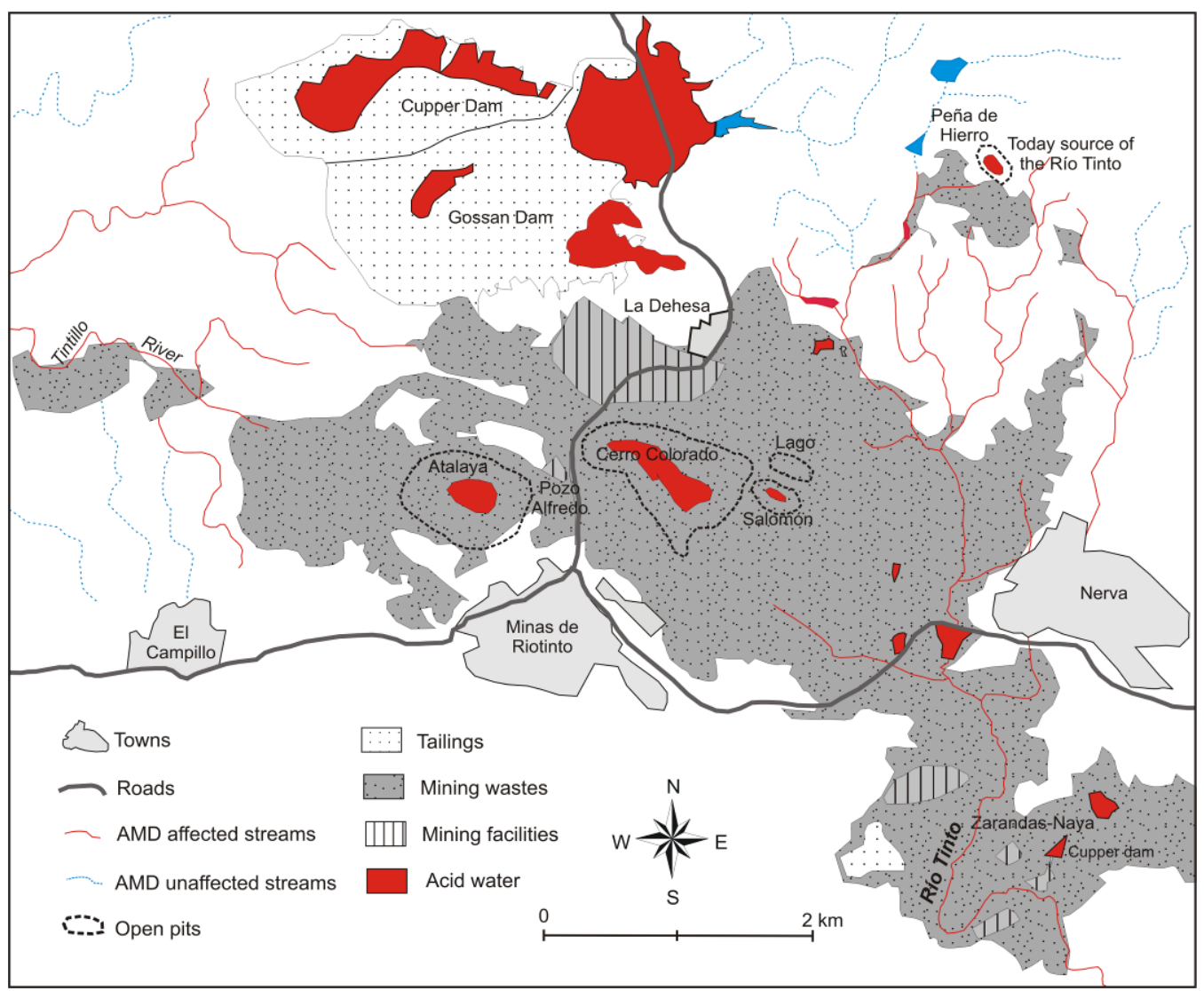

Figure 8. Current state of the Río Tinto headwaters. The represented area corresponds to the inner square in Figure 1.

From the eighteenth century to the present, the total sulphide production of the Peña de Hierro mine was $4 \mathrm{Mt}$, while the Río-Tinto mine has extracted $241 \mathrm{Mt}$ [41]. Prior to 1850, exploitation was negligible (Figure 4). The most important phase of production occurred in the 1970-2001 period, with almost $45 \%$ of all sulphides (plus $94 \mathrm{Mt}$ of gossan) being produced. Comparing these figures with the ancient extractions (Figure 10), we have found that throughout the Roman and pre-Roman periods (much longer than the contemporary exploitation) extractions were less than $2 \%$ of the total production.

\section{Impact of Mining on the Río Tinto}

\subsection{Background Conditions}

From the gossans that usually crown the sulphide deposits of the IPB, the age of onset of natural oxidation processes (ARD) of these deposits, and, therefore, the release of metals and acidity from the sulphides, can be obtained. There was already a natural process of oxidation of sulphides about $2 \mathrm{Ma}$ ago, leading to the appropriate conditions for the development of acidophilic bacteria [14]. In a recent more precise dating from a palaeomagnetic study at Río-Tinto gossan and other IPB gossans, the 
beginning of their formation (and therefore the origin of ARD processes) has been traced to the late Oligocene (>24 Ma) [42].

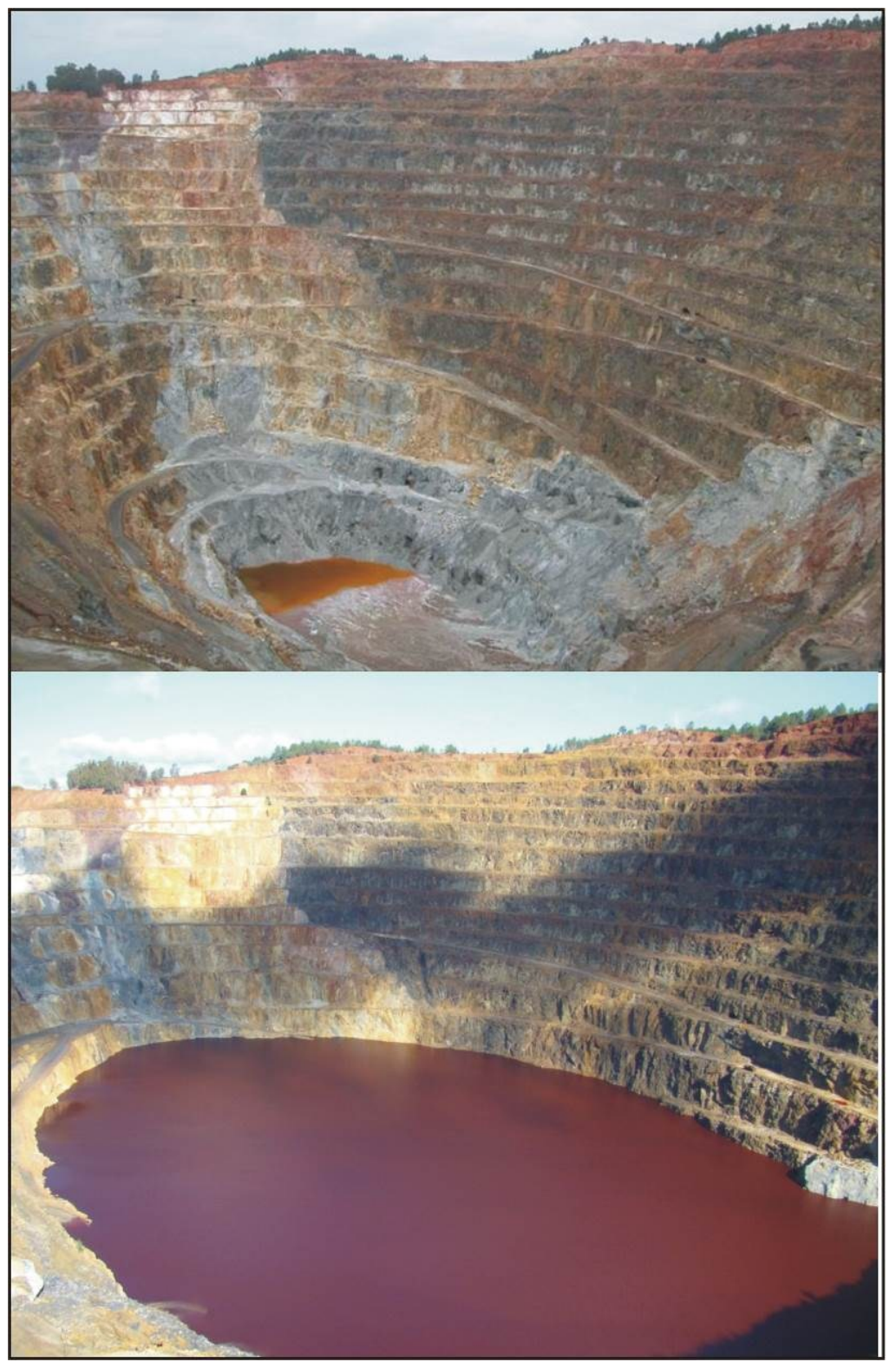

Figure 9. Atalaya open-pit before cessation of drainage pumpings in 2001 (up) and in 2014 (down).

An approximation of the amount of pollutants released at this stage, before mining, can be made. Considering the original mass of gossan (about $100 \mathrm{Mt}$ ), which must come from a mass of five times that of sulphide [43] and the existing average grades in the IPB (48\% sulphur, $0.8 \% \mathrm{Cu}, 2 \% \mathrm{Zn}$ [44], we found that the gossan formation of the Río-Tinto mine would produce $720 \mathrm{Mt}$ of sulphate (1 tonne of sulphur generates 3 tonnes of sulphates), $4 \mathrm{Mt}$ of $\mathrm{Cu}$ and $10 \mathrm{Mt}$ of $\mathrm{Zn}$. Dividing these figures by the time since the oxidation of sulphides started ( $24 \mathrm{Ma}$ ), it has been found that 30 tonnes of sulphates, $0.2 \mathrm{t}$ of $\mathrm{Cu}$ and $0.4 \mathrm{t}$ of $\mathrm{Zn}$ were released each year. This is an estimate with many simplifications and great uncertainty. However, these figures are three orders of magnitude lower than the amounts 
currently transported annually by the Río Tinto $(36,000 \mathrm{t}$ of sulphates, $470 \mathrm{t}$ of $\mathrm{Cu}$ and $860 \mathrm{t}$ of $\mathrm{Zn}$ [21]. This increase is in the range observed in other mines [29].

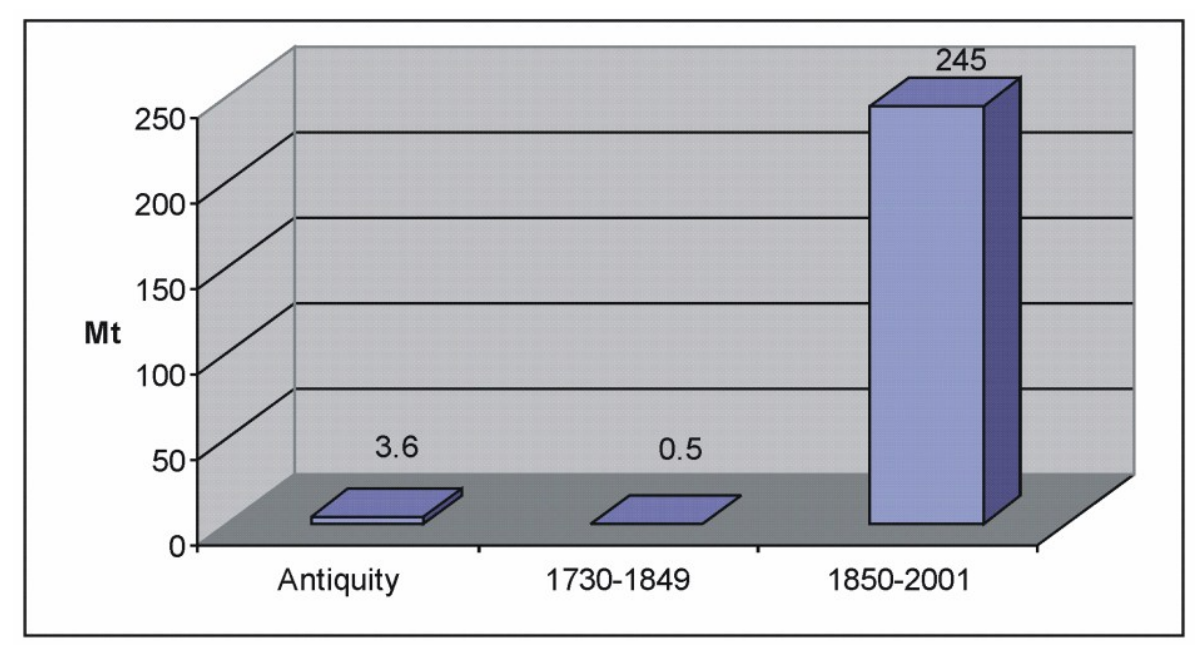

Figure 10. Sulphide production (run-of-mine ore) in the Río Tinto area throughout history.

\subsection{The Beginning of Mining}

Archaeological studies reveal the connection between the beginnings of mining and metal contamination in sediments of the Huelva estuary. From the analysis of molluscs shells consumed in a metallurgical village located about $30 \mathrm{~km}$ north of the city of Huelva [30], low concentrations of As, $\mathrm{Cu}$ and $\mathrm{Zn}$ from the sixth to fourth millennium $\mathrm{BC}$ have been found, although the background level is higher than that found off the coast of Portugal (which might be due to ARD discharges). In the third millennium BC, the content of these metals increased significantly and, in parallel, there is a noticeable decrease in tree pollen attributed to massive logging to feed smelters [30].

\subsection{The Roman Period}

After this first phase of initial exploitation, mining activity slowed to its resurgence in Roman times. As mentioned, Roman mining is a period of great activity causing sulphides to come into contact with atmospheric oxygen, increasing the levels of pollutants released into the environment. There is evidence of this contamination, transported by global atmospheric circulation, even in Greenland. By analysing ice cores, an increase in the concentration of lead, copper and other metals coinciding with the Roman era has been detected. Comparing the isotopic signature of lead to major mineral deposits existing in that period, is concluded that about $70 \%$ of the lead in the Greenland ice came from deposits of the IPB [45]. Similar conclusions were obtained from the analysis of the copper concentration in the ice [46], reflecting the enormous importance of IPB mining in Roman times.

\subsection{Since the End of the Roman Period until 1725}

After the Roman era, mining suffered a sharp decline, but continued intermittently until the modern age. The first written document on pollution by AMD from the Río-Tinto mine is a report from 1556 by Diego Delgado, appointed by King Philip II to investigate mining possibilities in this area, who described acidic leachates emerging from Roman galleries and caves [47]: "We also visited another 
cave which was full of water and from under which sprang a river said to be the Río Tinto. The reason why it is known as the Río Tinto is because it springs from vitriol, which in another part is known as copperas, used for ink". "No fish or other life existed in this river, neither do people or animals drink it, not are its waters used for anything else". "It has another property that if you place iron in the water it dissolves in a few days. This I tested and proved myself. I took a live frog and threw it in the river and it died without being able to leave the water".

This cave (Lago Cave; Figure 6) was actually an old mine in which the incisions of Roman picks could be recognized [36]. Also described in this report are huge spoil heaps and numerous traces of ancient mining activity in the area, including the source of the acidic River Tintillo (a tributary of the Odiel River) from a Roman adit (Figure 6). That is, although contamination levels should be lower than those of the Roman period, after many centuries of scarce mining activity, discharges of acidic leachates continued, reflecting the longevity of the processes of oxidation of sulphides [5]. However, that the headwater area of the Río Tinto was contaminated does not mean that there were similar levels of pollution as today. In fact, as stated below, the water quality of the Río Tinto near its mouths was good enough to be used for irrigation and urban supply.

\subsection{The Period $1725-1849$}

Mining activity in this period was low, as shown by mineral extraction (Figure 4) and, therefore, the pollution levels were also low. Several references to the Río Tinto can be found in [48]: "Water is good for cattle from its source to Salomon Hill, where high amounts of vitriol make it harmful to animals", "Along the municipality of Villarrasa the river fertilizes in both margins a portion of acres of arable land". Describing the town of Niebla: "is crossed by the Río Tinto, whose waters are used by the neighbors". Referring to the Río Tinto estuary: "It is abundant in all kinds of seafood and fish very exquisite".

That is, the Río Tinto had pollution problems downstream Salomon Hill (where the Lago Cave was located), but on its lower section it had good water quality. Interestingly, upstream the Lago Cave (Figure 8) the river was also of good quality. Today, the source of the Río Tinto is considered to be in the Peña de Hierro mine, about $2 \mathrm{~km}$ north of Lago Cave (which has disappeared due to mining). This implies that, due to the mining in Peña de Hierro that began in 1850, the reach from this point to Salomon Hill was contaminated. Namely, the source of the Río Tinto has been linked to mining activity since at least Roman times, and has changed depending on the opening of new mines.

\subsection{The Period 1850-2001}

Although exploitation in Peña de Hierro began in early 1850 and Río-Tinto mine production continued to increase at the beginning of this period, the mining boom was not until 1873, with the arrival of British investors. After 36 years of operation in Peña de Hierro was noted [49]: "On the source and upper reach of the river its waters and its tributaries are pure and crystalline, but when it receives water from the Río Tinto and Peña del Hierro mines are not only unprofitable for domestic use but, as is verified with the Odiel, damaging to vegetation, unsuitable for life of any beings and harmful to fish and shellfish from the estuary of Huelva when, after the summer, the first avenues washed the metal salts formed by evaporation and chemical precipitation...", "From light green when 
those waters leave the tanks in which the copper cementation occurs, go on losing such colour acquiring that of red wine, corresponding to the ferric salts, which are preserved in the river passing through Niebla...".

While before 1850 the Río Tinto waters fertilized the meadows next to Villarrasa and Niebla and being used by the neighbours for water supply [48], in 1886 the Río Tinto reached Niebla contaminated (red wine colour) [49]. That is, between 1850 and 1886 the Río Tinto suffered a major degradation. This process also occurred in many other rivers and streams in the IPB following the opening of a large number of sulphide mines and large-scale exploitation.

Also at this time, there was a great impact on the Huelva estuary, as shown in a study conducted in 1868 on bivalve shoals on the Spanish coast [50]: "This coast has been very abundant in oysters and other molluscs, everywhere, but for some years has been reduced to nil production, ignoring the causes, which may very well result from the movement and shipment of copper ore, which is made in considerable quantity and poisons the water". Probably, the disappearance of bivalves was due to the contaminant contributions of the Rivers Tinto and Odiel, rather than loading ore at the port.

This degradation of the IPB rivers was parallel to pollution provoked by the fumes of the "telera" calcinations [51]. The great development of the "teleras" in the second half of the nineteenth century led to large toxic clouds of sulphur fumes containing arsenic, that caused serious damage to crops and forests due to acid rain, as well as diseases and increased mortality of the inhabitants. In Río-Tinto mine, sulphur gases reached 500 tonnes per day, so the area became known as "The Valley of Lucifer" [31]. The complaints of the population due to the bad working conditions were suppressed, resulting in a massacre in 1888 [51]. The calcinations were gradually eliminated after these events; however, the pollution of rivers probably continued in parallel with the increase in mining production.

Throughout the twentieth century, pollution levels in the river should have reflected the mining activity. In this sense, the beginning of large-scale mining of $\mathrm{Cu}$ and gossan in Cerro Colorado from the 70s, and the generation of huge amounts of hydrometallurgical waste, must have led to a further deterioration in the conditions of the area, above all in the River Odiel basin where the tailing dams of $\mathrm{Cu}$ and gossan are located (Figure 8).

In Spain, the legislation to avoid the impact of mining on the environment was not implemented in an effective way until the $80 \mathrm{~s}$, and the awareness of environmental concerns by the population is even more recent. Before these dates, mining acid leachates discharging to the rivers were not considered a problem. In addition, many people think that the state of the river is due to natural processes.

From a study using geophysical methods in the area of Peña de Hierro, it was concluded that the source of acidity of the Río Tinto is a deep aquifer and that mining has little or no influence on the generation of the acidic waters carried by the river [28]. Nevertheless, these conclusions are not supported at all by the data provided by these authors. According to this work, the tritium values of waters in the zone confirm that both the acidic streams and the acidic springs are sourced by waters of subsurface origin that have a residence time of at least 60 years showing a deep flow of groundwater. However, the mean residence times from acidic waters in the zone are lower than 20 years, indicating a shallow groundwater flow through the artificial aquifer created by mining [52]. There are deep boreholes in the area with higher mean residence times [53], but this only show a slower groundwater flow at depth and the predominance of the surficial flow in the acidic springs. Also, the data of these 
authors [28] contradict the evolution of metal concentrations in the sedimentary record of the Huelva estuary and the Gulf of Cádiz (see below).

\subsection{Data from the Sedimentary Record}

The impact of mining in the IPB, and specifically in the Río Tinto mines, has been recorded in the sedimentary record. Before the beginning of mining, the release of acidity, sulphates, metals and metalloids by ARD occurred over millions of years. Although there were some zones with acidic conditions, these should be very restricted and the amount of pollutants released to the environment should be negligible compared to current levels. In a study of the alluvial terraces of the Río-Tinto, it has been documented that from the Middle Pleistocene to early Neolithic the concentrations of metals associated with sulphides are much lower than those in the most recent river terrace [54]. Also, there is no evidence of pre-mining contamination in the sedimentary record of the Huelva estuary. In the sediments older than 5000 years, concentrations of metals associated with sulphide mining are low, similar to averaged continental sediments $[55,56]$

However, current surface sediments, from the mine area to the estuary, show high concentrations of $\mathrm{Fe}, \mathrm{Ni}, \mathrm{Co}, \mathrm{Cr}, \mathrm{Cu}, \mathrm{Zn}$, etc., some orders of magnitude above Holocene background levels [57]. In a geochemical study of three cores from the Tinto estuary (between 2.4 and $3.2 \mathrm{~m}$ long), the highest levels of contaminants (up to $4122 \mathrm{ppm}$ of $\mathrm{Zn}$ and $1349 \mathrm{ppm}$ of $\mathrm{Cu}$ ) was obtained in the upper part due to the intensive mining from the second half of the nineteenth century [57]. The contaminant levels were also high in deeper samples dated to the Roman period (2020 years BP) or even before (3640 years $\mathrm{BP}$ ), showing that the estuary was polluted well before the large scale mining activities of the late nineteenth century [57]. An improvement in the quality of the ecosystem of the estuary of Huelva from the third to the nineteenth centuries was found from the study of microfossils in the Ría of Huelva due to the decrease of mining activities in this period [58].

Similar conclusions were obtained in a core $(15 \mathrm{~m}$ long) drilled in the Holocene sediments of the Tinto estuary, in which two anomalous horizons with very high metal contents (100 times over the background) were found [55]. The lower horizon (with $900 \mathrm{ppm}$ of As and $2500 \mathrm{of} \mathrm{Pb}$ ) also showed clastic pyrite grains and some small globules of vesicular glass similar to those of scorias and slags from metallurgical furnaces. The age of this horizon (4500 years B.P.) coincides with the beginning of mining in the IPB [30]. The trace metal contents in the older Holocene estuarine sediments were similar to averaged continental sediments. The influence of the Roman period did not appear in this core because there were an erosional hiatus. The second metal-rich layer (1400 pm of As and $5300 \mathrm{ppm}$ of $\mathrm{Pb}$ ) correspond to modern mining, and it is very rich in detrital pyrite grains similar to those of the huge stockpiles and tailings from the mining zone.

Data from another core (50 $\mathrm{m}$ long) near the confluence of the Tinto and Odiel estuaries also show background values of elements linked to sulphides before the beginning of mining, while the sediments near the surface show a high increment of $\mathrm{Fe}, \mathrm{Cu}, \mathrm{Zn}, \mathrm{As}$, etc. [56].

Associated with the great intensification of mining from the second half of the nineteenth century, there was a huge increase in the content of metals of the sediments, not only in the Huelva estuary, but even in samples taken on the Atlantic coast and the Gulf of Cadiz. In two cores collected near the mouth of the Guadalquivir River, a large increase in the concentration of $\mathrm{Zn}$ and $\mathrm{Cu}$ between 1840 and 
1890 was observed [59]. In these cores, the impact of older (pre-Roman) mining was not detected, probably because their effects were restricted to the Huelva estuary due to the lower intensity of mining.

An important industrial complex was developed in the estuary of the Ría of Huelva from 1967 contributing to the contamination of the estuary [22,57]. Since the 90s, the environmental authorities are making major efforts to reduce this type of pollution and the conditions in the estuary are improving. However, there remains a big problem due to contaminants from mining carried by the Tinto and Odiel Rivers.

A similar pattern in the distribution of mine-related contaminants in the sedimentary record has been observed in the estuary of the Guadiana River, also draining the IPB. Two cores were obtained in both side of the river (51 and $63 \mathrm{~m}$ long) sampling the complete sedimentary sequence of the last 11,000 years, until reaching the Variscan basement [60]. In this case, the complete history of mine-related contamination can be observed. Pre-mining background values of mine-related contaminants were recorded from the deeper part of the cores until the beginning of the mining activities in the IPB (4500 years BP). After this first peak of contaminants, other peaks can be seen upward in the cores corresponding to the main mining periods described in Section 3 until reaching present day conditions (see Figure 10 in [60]).

\section{Conclusions}

Pollution in the Río Tinto has paralleled the history of mining. Five periods with different levels of contamination can be considered:

1. The natural oxidation stage of sulphides and gossan formation by ARD. These natural processes occur very slowly, over millions of years. In the Río Tinto headwaters, natural acidic springs should exist, generating a high diversity of acidophilic eukaryotic organisms. However, this acidic water would be neutralized by water from other tributaries and the Río Tinto upstream the Ría de Huelva was of good quality. Although significantly higher than in other estuarine areas of the Gulf of Cadiz, the amounts of metals and metalloids released were small on a basin scale (in the order of a thousand times lower than today) as shown by the low levels of contaminants in the sediments of the Huelva estuary.

2. The first mining operations in the third millennium BC mark the beginning of anthropogenic pollution and produce a slight rise in background levels of metals in the sediments and fossils of the estuary. In the Bronze Age, with the Tartessian civilization, exploitation increased.

3. The Roman mining period was characterized by extraordinary activity considering the technology of the time. Drainage methods allow depths of $100 \mathrm{~m}$ to be reached. It is estimated that at this time 3.6 Mt of sulphides were extracted at Río-Tinto mine. The impact of mining on the rivers of the area has been registered by an increase of metals and metalloids in the estuarine sediments.

4. After Roman times until the mid-nineteenth century, a period of low-intensity mining occurred. However, due to the longevity of the processes of acid mine drainage, acidic leachates are still produced in the old Roman mines affecting areas of the headwater of the Río Tinto. Until 1850, the water between the Peña del Hierro and Lago Cave, and also in the lower reach of the river and in its estuary, was of good quality. 
5. In the late nineteenth century, with the arrival of foreign investors and the major mining boom, the total degradation of the Río Tinto occurred, as with many others rivers in the IPB. Pollution levels increased significantly in parallel with mining intensity, reaching a similar state as today. Due to the high toxic concentrations of elements entering into the estuary, loss of rich fishing at the Ría of Huelva also occurred. Also, at this stage, increased levels of metals from mining in the Gulf of Cadiz have been detected. This situation has been aggravated by mining in Cerro Colorado since 1970.

In summary, the current situation of the Rio Tinto is mainly due to the mining since the late nineteenth century, compounded by the last phase of large-scale exploitation since 1970. The natural processes of the formation of acid drainage can be considered to be negligible compared with those generated by mining, three orders of magnitude higher. As a result of the old contamination (over 140 years), "naturalization" of the process has occurred. That is, it has been assumed that the natural state of the river is as it is currently.

This has important implications in the current management of the river, as the Water Framework Directive of the European Union (Directive 2000/60/EC) requires the recovery of the natural conditions of aquatic ecosystems. Although technically possible, the recovery of the Río Tinto would require enormous economic resources.

Due to the rise in the price of copper on the international markets from 2004-2008, a resurgence of mining in the IPB has been initiated and the reopening of Río Tinto mine has been requested. Currently, it is possible to reconcile mining with environmental sustainability. Moreover, the current interest in reopening many of the old exploitations is a good opportunity for restoration, requiring mining companies reinvest some of the profits generated into the recovery of the environment.

A large area of the Río Tinto headwaters is protected for its scenic interests, rich mining heritage and extreme environments where acidophilic bacteria develop. It is possible to leave some areas in the headwaters of the Río Tinto to preserve these ecosystems and the mining heritage and, at the same time, begin restoration actions to reduce the huge amounts of toxic elements that have a profound impact on the Río Tinto and its estuary.

\section{Acknowledgements}

The authors thank the comments and suggestions of three anonymous reviewers, which helped us to improve the original manuscript.

\section{Author Contributions}

Manuel Olías had the original idea for the study. Both authors did the research. Manuel Olías drafted and wrote the first version of the manuscript. José Miguel Nieto revised and edited the paper. Both the authors read and approved the final manuscript.

\section{Conflicts of Interest}

The authors declare no conflict of interest. 


\section{References}

1. Hudson-Edwards, K.A.; Jamieson, H.E.; Lottermoser, B.G. Mine Water: Past, Present and Future. Elements 2011, 7, 375-380.

2. Simate, G.S.; Ndlovu, S. Acid mine drainage: Challenges and opportunities. J. Environ. Chem. Eng. 2014, 2, 1785-1803.

3. Younger, P.L.; Wolkersdorfer, C. Mining impacts on the fresh water environment: Technical and managerial guidelines for catchment scale management. Mine Water Environ. 2004, 23, 2-80.

4. Amos, R.T.; Blowes, D.W.; Bailey, B.L.; Sego, D.C.; Smith, L.; Ritchie, A.I.M. Waste-rock hydrogeology and geochemistry. Appl. Geochem. 2015, 57, 140-156.

5. Younger, P. The longevity of minewater pollution: A basis for decision making. Sci. Total Environ. 1997, 194-195, 457-466.

6. Adamides, N.G. Rio Tinto (Iberian Pyrite Belt): A world-class mineral field reopens. App. Earth. Sci. 2013, 122, 1-15.

7. Tornos, F. Environment of formation and styles of volcanogenic massive sulfides: The Iberian Pyrite Belt. Ore Geol. Rev. 2006, 28, 259-307.

8. Sáez, R.; Pascual, E.; Toscano, M.; Almodóvar, G.R. The Iberian type of volcano-sedimentary massive sulphide deposits. Miner. Deposita 1999, 34, 549-570.

9. Cánovas, C.R.; Hubbard, C.G.; Olías, M.; Nieto, J.M.; Black, S.; Coleman, M.L. Hydrochemical variations and contaminant load in the Río Tinto (Spain) during flood events. J. Hydrol. 2008, $350,25-40$.

10. Nordstrom, D.K. Mine waters: Acidic to circumneutral. Elements 2011, 7, 393-398.

11. López-Archilla, A.I.; Marin, I.; Amils, R. Microbial community composition and ecology of an acidic aquatic environment: The Tinto River, Spain. Microb. Ecol. 2001, 41, 20-35.

12. Zettler, L.A.A.; Gomez, F.; Zettler, E.; Keenan, G.; Amils, R.; Sogin, M.L. Eukaryotic diversity in Spain's River of Fire. Nature. Available online: http://nematodes.org/teaching/retired_teaching/ ecology4/Zettler_river_of_fire.pdf(accessed on 9 May 2002).

13. González-Toril, I.; Llobet-Brossa, E.; Amann, R.; Amils, R. Microbialecology of an extreme acidic environment, the Tinto River. Appl. Environ. Microb. 2003, 69, 4853-4865.

14. Fernández-Remolar, D.C.; Morris, R.V.; Gruener, J.E.; Amils, R.; Knoll, A.H. The Río Tinto Basin, Spain: Mineralogy, sedimentary geobiology, and implications for interpretation of outcrop rocks at Meridiani Planum. Mars Earth Planet. Sci. Lett. 2005, 240, 149-167.

15. Amils, R.; González-Toril, E.; Fernández-Remolar, D.; Gómez, F.; Aguilera, A.; Rodríguez, N.; Malki, M.; García-Moyano, A.; Fairen, A.G.; de la Fuente, V.; Sanz, J.L. Extreme environments as Mars terrestrial analogs: The Río Tinto case. Planet Sp. Sci. 2007, 55, 370-381.

16. Amils, R.; Fernández-Remolar, D.; The IPBSL Team. Río Tinto: A geochemical and mineralogical terrestrial analogue of Mars. Life 2014, 4, 511-534.

17. Hubbard, C.G. Acid Mine Drainage Generation and Transport Processes in the Tinto River, SW Spain. Ph.D. Thesis, University of Reading, Reading, UK, 2007.

18. Cánovas, C.R.; Olías, M.; Nieto, J.M. Metal (loid) attenuation processes in an extremely acidic river: The Río Tinto (SW Spain). Water Air Soil Pollut. 2014, 225, doi:10.1007/s11270-013-1795-7. 
19. Lottermoser, B.G. Evaporative mineral precipitates from a historical smelting slag dump, Rio Tinto, Spain. Neues Jahrbuch Fur Mineralogie-Abhandlungen 2005, 181, 183-190.

20. Cánovas, C.R. La calidad del agua de los ríos Tinto y Odiel. Evolución Temporal y Factores Condicionantes de la Movilidad de los Metales. Ph.D. Thesis, University of Huelva, Huelva, Spain, 2008.

21. Olías, M.; Cánovas, C.R.; Nieto, J.M.; Sarmiento, A.M. Evaluation of the dissolved contaminant load transported by the Tinto and Odiel rivers (South West Spain). Appl. Geochem. 2006, 21, 1733-1749.

22. Vicente-Martorell, J.J.; Galindo-Riaño, M.D.; García Vargas, M.; Granado-Castro, M.D. Bioavailability of heavy metals monitoring wáter, sediment and fish species from a polluted estuary. J. Hazard Mater. 2009, 162, 823-836.

23. Buckby, T.; Black, S.; Coleman, M.L.; Hodson, M.E. Fe-sulphate-rich evaporative mineral precipitates from the Río Tinto, southwest Spain. Miner. Mag. 2003, 67, 263-278.

24. Flores Caballero, M. Las antiguas explotaciones de Río Tinto; Instituto de Estudios Onubenses: Huelva, Spain, 1981.

25. Ruiz Ballesteros, E.; Rubio de Miguel, E. Lo natural y lo contaminado, ironías del Río Tinto. In Patrimonialización de la Naturaleza, el Marco Social de las Politicas Ambientales; Oriol, B., Pascual, J.J., Vaccaro, I., Eds.; Ankulegi Antropologia Elkartea: San Sebastián, Spain, 2008; pp. $165-180$.

26. Sánchez-Andrea, I.; Nittel, K.; Amann, R.; Amils, R.; Sanz, J.L. Quantification of Tinto River sediment microbial communities: Importance of sulfate-reducing bacteria and their role in attenuating acid mine drainage. Appl. Environ. Microbiol. 2012, 78, 4638-4645.

27. Pérez Macías, J.A.; Delgado Domínguez, A. Ingeniería minera antigua y medieval en el suroeste ibérico. Boletín Geológico y Minero 2012, 122, 3-16.

28. Gómez-Ortiz, D.; Fernández-Remolar, D.C.; Granda, A.; Quesada, C.; Granda, T.; Prieto-Ballesteros, O.; Molina, A.; Amils, R. Identification of the subsurface sulfide bodies responsible for acidity in Río Tinto source water, Spain. Earth Planet. Sci. Lett. 2014, 391, 36-41.

29. Nordstrom, D.K. Baseline and premining geochemical characterization of mined sites. App. Geochem. 2015, 57, 17-34.

30. Nocete, F.; Alex, E.; Nieto, J.M.; Sáez, R.; Bayona, M.R. An archaelogical approach to regional environmental pollution in the south-western Iberian Peninsula related to Third Millenium B.C mining and metallurgy. J. Archaeol. Sci. 2005, 32, 1566-1576.

31. Carrasco Martiañez, I. Historia en la Faja Pirítica. Bocamina 2000, 5, 8-49.

32. Pinedo Vara, I. Piritas de Huelva. Su Historia, Minería y Aprovechamiento; Suc. de Rivadeneyra: Madrid, Spain, 1963.

33. Rothenberg, B.; García Palomero, F. The Rio Tinto enigma-no more. Inst. Archaeo. Metall. Stud. Newsl. 1986, 8, 3-5.

34. Ortiz Mateo, M. Las escorias de Riotinto. De Re Metallica 2004, 2, 9-22.

35. Ortiz Mateo, M.; Romero Macías, E. La metalurgia en las minas de Riotinto, desde su creación al alquiler del Marqués de Remisa (1725-1849) y obtención de indicadores ambientales del consumo de combustible en los procesos metalúrgicos. Boletín Geológico y Minero 2004, 115, $103-114$. 
36. Ezquerra Bayo, J. Memorias Sobre las Minas Nacionales de Rio-Tinto; Viuda de D. Antonio Yenes: Madrid, Spain, 1852.

37. Fernández-Posse, M.D.; Sánchez-Palencia, F.J. Riotinto: La memoria antigua desde la antigüedad. Clásicos de la Arqueología de Huelva 1996, 6, 51-97.

38. Maurín, M. Huella, memoria y patrimonio territorial de la minería española. Una síntesis cartográfica. Ería 2011, 86, 187-214.

39. Carrasco Martiañez, I. La Faja Pirítica Ibérica ¿Crisis terminal o renacimiento de un distrito histórico? In Metallum. La Minería Suribérica; Romero, E., Pérez Macías, J.A., Eds.; Servicio de, Publicaciones: Universidad de Huelva, Huelva, Spain, 2004; pp. 203-224.

40. Delgado Domínguez, A.; Regalado Ortega, M.C. Catálogo del patrimonio minero industrial de la mina Peña de Hierro (Nerva, Huelva, España). De Re Metallica 2012, 18, $13-27$.

41. Moreno Bolaños, A. Mineral extraído en minas de Riotinto (1725-2002). In Río Tinto. Historia, Patrimonio Minero y Turismo Cultural; Pérez Macías, J.A., Delgado Domínguez, A., Pérez López, J.M., García Delgado, F.J., Eds.; Servicio de Publicaciones: Universidad de Huelva, Huelva, Spain, 2011, pp. 761-770.

42. Essalhi, M.; Sizaret, S.; Barbanson, L.; Chen, Y.; Lagroix, F.; Demory, F.; Nieto, J.M.; Sáez, R.; Capitán, M.A. A case study of the internal structures of gossans and weathering processes in the Iberian Pyrite Belt using magnetic frabrics and paleomagnetic dating. Miner. Deposita 2011, 46, 981-999.

43. García Palomero, F. Yacimientos de la Faja Pirítica Ibérica. In Metallum. La Minería Suribérica; Romero, E., Pérez Macías, J.A., Eds.; Servicio de Publicaciones: Universidad de Huelva, Huelva, Spain, 2004; pp. 13-29.

44. Leistel, J.M.; Marcoux, E.; Thiéblemont, D.; Quesada, C.; Sánchez, A.; Almodóvar, G.R.; Pascual, E.; Sáez, R. The volcanic-hosted massive sulphide deposits of the Iberian Pyrite Belt. Miner. Deposita 1998, 33, 2-30.

45. Rosman, K.; Chisholm, W.; Hong, S.; Candelone, J.P.; Boutron, C.F. Lead from Carthaginian and Roman Spanish mines isotopically identified in Greenland ice dated from 600 B.C. to 300 A.D. Environ. Sci. Technol. 1997, 31, 3413-3421.

46. Hong, S.; Candelone, J.P.; Patterson, C.C.; Boutron, C.F. History of Ancient copper Smelting Pollution During Roman and Medieval Times Recorded in Greenland Ice. Science 1996, 272, 246-249.

47. Salkield, L.U. A Technical History of the Rio Tinto Mines: Some Notes on Exploitation from Pre-Phoenician Times to the 1950s; The Institute of Mining and Metallurgy: London, UK, 1987.

48. Madoz, P. Diccionario Geográfico-Estadístico-Histórico de España y Sus Posesiones de Ultramar; Est. Literario-Tipográfico de P. Madoz y L. Sagasti: Madrid, Spain, 1850.

49. Gonzalo y Tarín, J. Descripción Física, Geológica y Minera de la Provincia de Huelva; Memorias de la Comisión del Mapa Geológico de España: Madrid, Spain, 1886.

50. García del Hoyo, J.J. El impacto económico de la expansión minera del siglo XIX: Efectos inducidos en el tejido productivo de la provincia de Huelva. In Patrimonio Geológico y Minero. Una Apuesta Por el Desarrollo Local Sostenible; Romero, E., Ed.; Servicio de Publicaciones, Universidad de Huelva: Huelva, Spain, 2010; pp. 57-70. 
51. Ferrero Blanco, M.D. Capitalismo Minero y Resistencia Rural en el Suroeste Andaluz. Río Tinto, 1873-1900; Servicio de Publicaciones de la Universidad de Huelva: Huelva, Spain, 1999.

52. Olías, M.; Nieto, J.M. Comment on "Identification of the subsurface sulfide bodies responsible for acidity in Río Tinto source water, Spain". Earth Planet. Sci. Lett. 2014, 403, 456-458.

53. Gómez-Ortiz, D.; Fernández-Remolar, D.C.; Granda, A.; Quesada, C.; Granda, T.; Prieto-Ballesteros, O.; Molina, A.; Amils, R. Reply to Comment on "Identification of the subsurface sulfide bodies responsible for acidity in Río Tinto source water, Spain”. Earth Planet. Sci. Lett. 2014, 403, 459-462.

54. Cáceres, L.M.; Olías, M.; De Andrés, J.R.; Rodríguez-Vidal, J.; Clemente, L.; Galván, L.; Medina, B. Geochemistry of Quaternary sediments in terraces of the Tinto River (SW Spain): Palaeoenviromental implications. Catena 2013, 101, 1-10.

55. Leblanc, M.; Morales, J.A.; Borrego, J.; Elbaz-Poulichet, F. 4500 Year old mining pollution in southwestern Spain: Long-term implications for modern mining pollution. Econ. Geol. 2000, 95, 655-661.

56. López-González, N.; Borrego, J.; Ruiz, F.; Carro, B.; Lozano-Soria, O.; Abad, M. Geochemical variations in estuarine sediments: Provenance and environmental changes (Southern Spain). Estuar. Coast. Shelf Sci. 2006, 67, 313-320.

57. Davis, R.A.; Welty, A.T.; Borrego, J.; Morales, J.A.; Pendón, J.G.; Ryan, J.G. Río Tinto estuary (Spain): 5000 Years of pollution. Environ. Geol. 2000, 39, 1107-1116.

58. Ruiz, F.; Borrego, J.; Gonzalez-Regalado, M.L.; López-González, N.; Carro, B.; Abad, M. Interaction between sedimentary processes, historical pollution and microfauna in the Tinto Estuary (SW Spain). Environ. Geol. 2009, 58, 779-783.

59. Van Geen, A.; Adkins, J.F.; Boyle, E.A.; Nelson, C.H.; Palanques, A. A 120-year record of widespread contamination from mining of the Iberian Prite Blt. Geol. 1997, 25, 291-294.

60. Delgado, J.; Boski, T.; Nieto, J.M.; Pereira, L.; Moura, D.; Gomes, A.; Sousa, C.; García-Tenorio, R. Sea-level rise and anthropogenic activities recorded in the late Pleistocene/Holocene sedimentary infill of the Guadiana Estuary (SW Iberia). Quat. Sci. Rev. 2012, 33, 121-141.

(C) 2015 by the authors; licensee MDPI, Basel, Switzerland. This article is an open access article distributed under the terms and conditions of the Creative Commons Attribution license (http://creativecommons.org/licenses/by/4.0/). 